\title{
Preparation of Interface-Assembled Carbonyl Reductase and Its Application in Synthesis of S-Licarbazepine in Toluene/Tri-HCl Buffer Biphasic System
}

\author{
Zhimin $\mathrm{Ou}{ }^{1, *}$, Jiahui $\mathrm{Xu}^{1}$, Yangping $\mathrm{Niu}^{2}$ and Jian Cui ${ }^{2}$ \\ ${ }^{1}$ College of Pharmaceutical Science, Zhejiang University of Technology, Hangzhou, Zhejiang 310014, China \\ ${ }^{2}$ Linan People's Hospital, Linan, Hangzhou, Zhejiang 311300, China; oozzmm@zjut.cn \\ * Correspondence: oozzmm@zjut.edu.cn; Tel.: +86-153-5546-8685
}

\begin{abstract}
S-licarbazepine was prepared by asymmetric reduction of oxcarbazepine with interface-assembled carbonyl reductase at the interface of oil/water biphasic system. The carbonyl reductase was conjugated with polystyrene in the surface of toluene/Tris- $\mathrm{HCl}$ biphasic system and formed a surfactant-like structure. The conversion and enantiometric excess of S-licarbazepine reached $97.39 \%$ and $99.6 \%$ when $3.97 \mathrm{mmol} / \mathrm{L}$ oxcarbazepine was reduced by interface-assembled carbonyl reductase with $60 \mathrm{~g} / \mathrm{L}$ ethanol as co-substrate in toluene/Tris-HCl(12.5:10) biphasic system at $30^{\circ} \mathrm{C}, 180 \mathrm{rpm}$ for $6 \mathrm{~h}$.
\end{abstract}

Keywords: Biotransformation; interface-assembling carbonyl reductase; oxcarbazepine; polystyrene; S-licarbazepine

\section{Introduction}

Eslicarbazepine acetate is approved as a voltage-gated sodium channel inhibitor for the treatment of epileptic seizures in adults [1]. S-licarbazepine is a key intermediate of eslicarbazepine acetate and an active metabolite of oxcarbazepine [2]. The synthesis of S-licarbazepine has been studied by chemical and enzymatic routes [3-4]. The current efficient routes for the synthesis of S-licarbazepine generally involve the asymmetric reduction of oxcarbazepine with expensive chiral $\mathrm{Ru}$ or $\mathrm{Rh}$ as catalyst or resolution of racemic licarbazepine followed by acylation and hydrolyzation [5]. It is difficult for oxcarbazepine and S-licarbazepine to be isolated from reaction mixture using chemical methods. Preparation of S-licarbazepine by biotransformation has been reported with Sacchromyces cerevisiae [6] or Pichia methanolica [7] as catalysts. 
Compared with the chemical method, biotransformation is mild, high conversion and outstanding stereoselectivity [8]. However, the solubility of oxcarbazepine or S-licarbazepine in water is so low that production efficiency is not high in biotransformation [9]. In order to improve the production capacity of biotransformation, interface-assembled carbonyl reductase was used in the reduction of oxcarbazepine to prepare S-licarbazepine in this paper.

Catalytic ability of enzyme protein molecules in membranes is the basis for biological function of cell or organelle [10]. This phenomenon provides a good idea for preparation of interface-assembled enzyme. Enzyme protein molecule can be connected with macromolecular polymer to prepare the interface-assembled enzyme by simulating the cell membrane structure [11]. Interface-assembled enzyme contains both hydrophilic group and hydrophobic group and just like the surfactant with enzyme protein as main body [12]. The interface-assembled enzyme can be used as catalyst for biotransformation in oil/water two phase system and gather at the surface of oil-water interface, which the hydrophobic group of macromolecular polymer stretches to the oil phase and enzyme protein embedded in the water phase $[13,14]$. The interface-assembled enzyme play a good catalytic function at the oil-water interface because substrate dissolved in water or organic phase can access to enzyme easily [15]. The interface-assembled enzyme is the ideal biological catalyst in organic/water two phase systems. High conversion efficiency can be obtained with the interface-assembled enzyme as catalyst in organic/water two phase systems. 


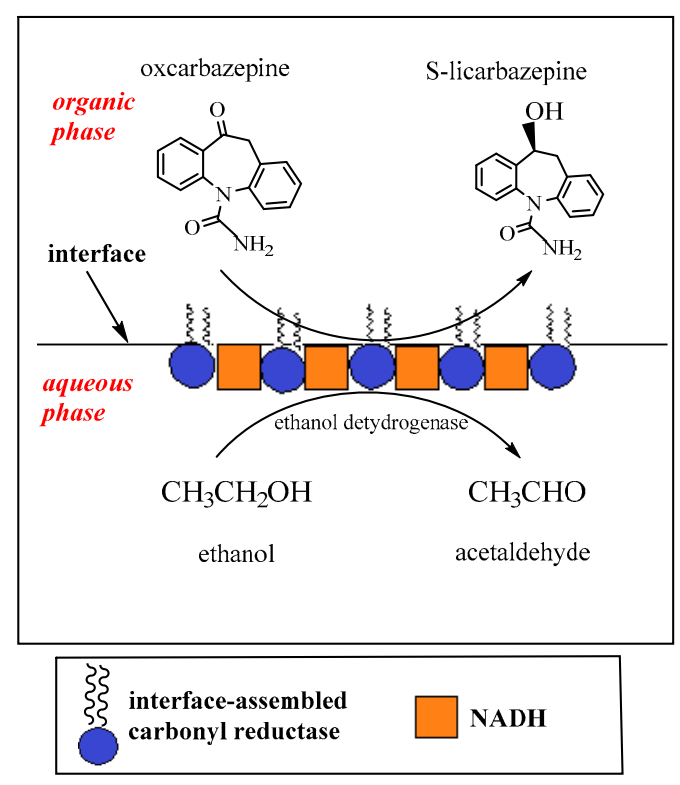

Figure 1. Mechanism of synthesis of S-licarbazepine by asymmetric reduction of oxcarbazepine with interface-assembled carbonyl reductase as catalyst

In this paper, the interface-assembled carbonyl reductase was prepared in the interface of toluene/Tris-HCl buffer biphasic system. S-licarbazepine was synthesized by asymmetric reduction of oxcarbazepine in toluent/Tris- $\mathrm{HCl}$ buffer biphasic system with interface-assembled carbonyl reductase as catalyst. Figure 1 explained the mechanism of synthesis of S-licarbazepine. S-licarbazepine was prepared by asymmetric reduction of oxcarbazepine with interface-assembled carbonyl reductase as catalyst and NADH as coenzyme at the surface of organic phase and aqueous phase. Coenzyme NADH was regenerated by addition of co-substrate ethanol. Ethanol was converted to acetaldehyde by ethanol dehydrogenase and $\mathrm{NAD}^{+}$acquired hydrogen ion to form NADH. Oxcarbazepine can be reduced efficiently with sufficient NADH as coenzyme. The effects of polystyrene concentration, carbonyl reductase concentration, volume ratio of organic and aqueous phase, co-substrate, $\mathrm{pH}$, temperature, substrate concentration and shaker speed on conversion and enantiometric excess of S-licarbazepine were studied in detail.

\section{Results and discussion}

\subsection{Effect of organic solvent on reduction}

Eight kinds of hydrophobic organic solvents were used as organic phase for 
preparation of the interface-assembling carbonyl reductase in this research. Polystyrene easily dissolves in benzene, toluene, dichloromethane and chloroform. However, it is slightly soluble in hexane, heptane, butanol and dibutyl phthalate. Enantiometric excess of S-licarbazepine has a high value in toluene, dichloromethane and chloroform. Table 1 showed that the conversion and enantiometric excess of S-licarbazepine reached $65.3 \%$ and $97.9 \%$ when the toluene was used as the organic phase. Types of organic solvents have great effective on the reduction activity and stereoselectivity of interface-assembled carbonyl reductase. The spatial conformation of interface-assembled carbonyl redutase was different in different organic/Tris- $\mathrm{HCl}$ solvents. Interface-assembling carbonyl reductase has a good reduction activity and high stereoselectivity in toluene/Tris- $\mathrm{HCl}$ buffer. The toluene/tris- $\mathrm{HCl}$ was used as optimal reaction biophasic system for further study.

Table.1 Effect of organic solvents on reduction

\begin{tabular}{ccc}
\hline Organic solvent/Tris-HCl & $\begin{array}{c}\text { Total } \\
\text { conversion }\end{array}$ & $\begin{array}{c}\text { Enantiometric excess } \\
\text { of S-licarbazepine (\%) }\end{array}$ \\
\hline toluene/Tris-HCl & 65.34 & 97.90 \\
benzene/Tris-HCl & 31.51 & 75.21 \\
dichloromethane/Tris-HCl & 51.34 & 94.78 \\
chloroform/Tris-HCl & 41.85 & 90.08 \\
hexane/Tris-HCl & 4.02 & 80.28 \\
dibutyl phthalate/Tris-HCl & 2.21 & 85.44 \\
n-butanol/Tris-HCl & 2.19 & 73.90 \\
n-heptane/Tris-HCl & 6.65 & 77.25 \\
\hline
\end{tabular}

(Reaction condition: $1 \mathrm{ml} / \mathrm{ml} \mathrm{CBR,} 2.5 \mathrm{mg} / \mathrm{L} \mathrm{PS}, 180 \mathrm{rpm}, 30{ }^{\circ} \mathrm{C}$ )

\subsection{Effect of carbonyl reductase concentration on catalytic activity of} interface-assembled carbonyl reductase

The concentration of carbonyl reductase in aqueous phase has a great effect on the catalytic activity of interface-assembled enzyme. Optimal concentration of carbonyl reductase will benefit for the conjugation of the carbonyl reductase with polymer in 
the interface region when the concentration of polystyrene remains unchanged. Figure 2 showed that conversion increased with the increase of carbonyl reductase concentration when the concentration of polystyrene in toluene was $2.5 \mathrm{mg} / \mathrm{L}$. Conversion got to $70 \%$ when the carbonyl reductase concentration was $0.8 \mathrm{ml} / \mathrm{ml}$. Conversion will not increase when the carbonyl reductase concentration was over 0.8 $\mathrm{ml} / \mathrm{ml}$. The changes of carbonyl reductase concentration had no influence on the enantiometric excess of S-licarbazepine. Therefore, the optimum concentration of carbonyl reductase was $0.8 \mathrm{ml} / \mathrm{ml}$.

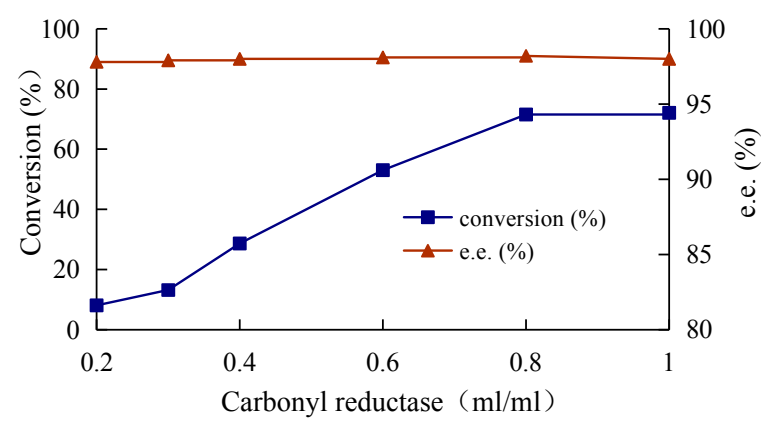

Figure 2. Effect of carbonyl reductase on reduction

(Reaction condition: $2.5 \mathrm{mg} / \mathrm{L} \mathrm{PS}, 180 \mathrm{rpm}, 30{ }^{\circ} \mathrm{C}$, volume ratio of toluene and Tris- $\mathrm{HCl}$ buffer is $1: 1$ )

\subsection{Effect of polystyrene concentration on catalytic activity of interface-assembled} carbonyl reductase

Optimal polystyrene concentration is good for preparation of high catalytic activity interface-assembled enzyme in the toluene/Tris-HCl biphasic system. The carbonyl reductase can not be conjugated sufficiently when the polystyrene concentration is low. Excessive polystyrene affects the mass transfer. Figure 3 showed that the conversion significantly increased when the polystyrene concentration gradually increased from $1.25 \sim 3.75 \mathrm{mg} / \mathrm{ml}$, the conversion decreased when the polystyrene concentration reached $3.75 \mathrm{mg} / \mathrm{ml}$. However, the change of polystyrene concentration almost had no influence on the enantiometric excess of S-licarbazepine. Therefore, the optimal polymer concentration was $3.75 \mathrm{mg} / \mathrm{ml}$. 


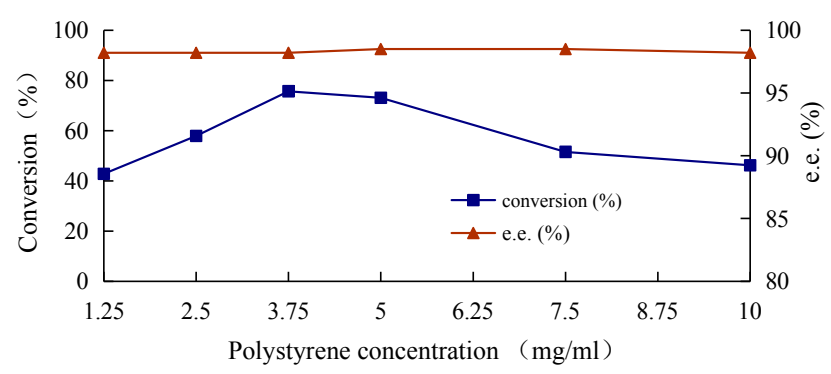

Figure 3. Effect of polystyrene on reduction

(Reaction condition: $0.8 \mathrm{ml} / \mathrm{ml} \mathrm{CBR,} 180 \mathrm{rpm}, 30^{\circ} \mathrm{C}$, volume ratio of toluene and Tris- $\mathrm{HCl}$ buffer is $1: 1$ )

2.4 Effect of volume ratio of toluene and Tris-HCl buffer on reduction of oxcarbazepine

The volume ratio of toluene and Tris- $\mathrm{HCl}$ buffer was defined as $\mathrm{V}_{\mathrm{o}} / \mathrm{V}_{\mathrm{T}}$ value. $\mathrm{V}_{\mathrm{o}}$ and $\mathrm{V}_{\mathrm{T}}$ were the volume of toluene and Tris- $\mathrm{HCl}$ buffer respectively. The change of $\mathrm{V}_{\mathrm{o}} / \mathrm{V}_{\mathrm{T}}$ value affects the interfacial area of the biphasic system and the biological catalytic efficiency [16]. The effect of different volume ratio on conversion was investigated. Figure 4 showed that the conversion and enantiometric excess of S-licarbazepine increased with the increase of $\mathrm{V}_{\mathrm{o}} / \mathrm{V}_{\mathrm{T}}$ value. The $\mathrm{V}_{\mathrm{o}} / \mathrm{V}_{\mathrm{T}}$ value has a great effect on the reduction conversion and the configuration of S-licarbazepine. The conversion and the enantiometric excess of S-licarbazepine both got to the maximum $79.9 \%$ and $97.9 \%$ when the $\mathrm{V}_{\mathrm{o}} / \mathrm{V}_{\mathrm{T}}$ value was $12.5: 10$. Therefore, 12.5:10 $\left(\mathrm{V}_{\mathrm{o}} / \mathrm{V}_{\mathrm{T}}\right)$ was determined to be the optimum volume ratio of toluene and Tris-HCl buffer.

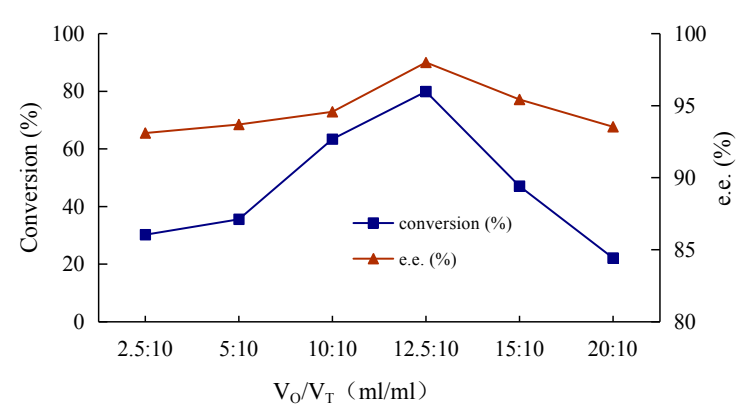

Figure 4. Effect of volume ratio of toluene and Tris- $\mathrm{HCl}$ buffer on reduction

(Reaction condition: $0.8 \mathrm{ml} / \mathrm{ml} \mathrm{CBR,} 2.38 \mathrm{mmol} / \mathrm{L}$ oxcarbazepine, $0.02 \mathrm{~mol} / \mathrm{L} \mathrm{NADH}, 50 \mathrm{~g} / \mathrm{L}$ glucose, $180 \mathrm{rpm}$, $30{ }^{\circ} \mathrm{C}$ )

\subsection{Effect of $N A D H$ on reduction}

NADH was added into Tris-HCl buffer as coenzyme to provide reducer for reduction of oxcarbazepine [17]. Different concentration of NADH was added in Tris-HCl 
buffer to study the effect of NADH on reduction. Figure 5 showed that the conversion increased gradually with the increase of NADH concentration. $0.08 \mathrm{~mol} / \mathrm{L} \mathrm{NADH}$ was the optimum concentration. The concentration of NADH has no effect on enantiometric excess of S-licarbazepine. The enantiometric excess of S-licarbazepine maintained about $97.9 \%$.

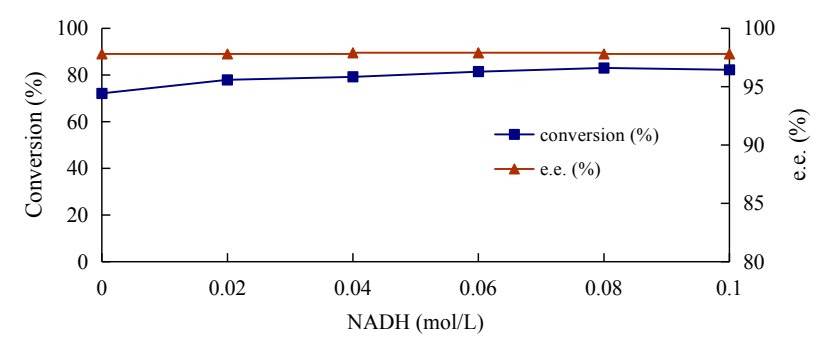

Figure 5. Effect of NADH on reduction

(Reaction condition: $0.8 \mathrm{ml} / \mathrm{ml} \mathrm{CBR,} \mathrm{V}_{\mathrm{o}} / \mathrm{V}_{\mathrm{T}}$ 12.5:10, $2.38 \mathrm{mmol} / \mathrm{L}$ oxcarbazepine, $50 \mathrm{~g} / \mathrm{L}$ glucose, $180 \mathrm{rpm}, 3{ }^{\circ} \mathrm{C}$ )

\subsection{Effect of co-substrate on reduction}

Addition of co-substrate is benefit for regeneration of NADH [18]. Glucose, ethanole, methanol, sucrose and isopropanol were added in Tris-HCl buffer as co-substrate. The effects of co-substrates on reduction were investigated. Figure 6(a) showed that 60 $\mathrm{g} / \mathrm{L}$ ethanol was the optimal co-substrate. $60 \mathrm{~g} / \mathrm{L}$ ethanol is benefit for the NADH regeneration. Coenzyme regeneration mechanism was showed in figure 1. Ethanol was converted to form acetaldehyde by ethanol dehydrogenase and coenzyme $\mathrm{NADH}^{+}$was transformed to NADH. NADH was regenerated to provide hydrogen donor for the synthesis of S-licarbazepine. Figure 6(b) showed that different co-substrates almost had no influence on the enantiometric excess of S-licarbazepine. Therefore, the optimum co-substrate was

$60 \mathrm{~g} / \mathrm{L}$ ethanol.

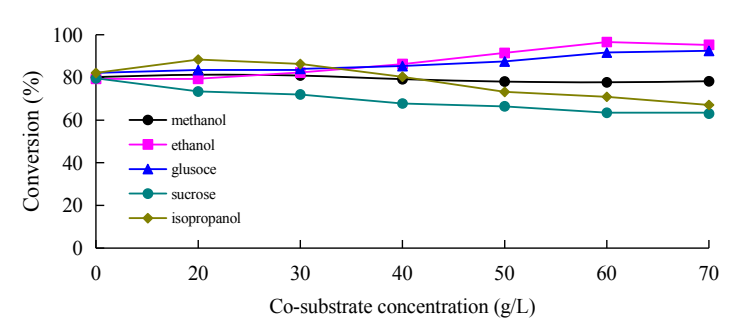

(a)

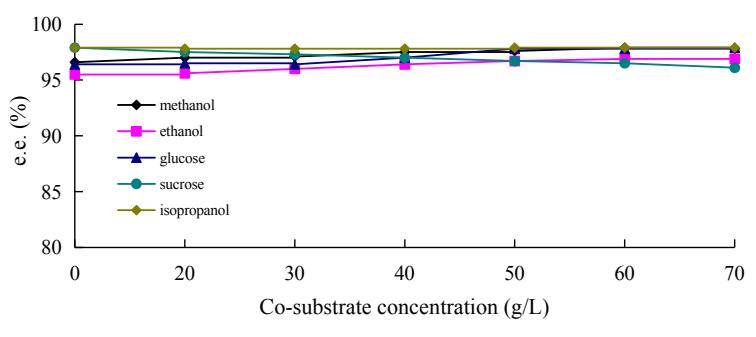

(b)

Figure 6. Effect of different co-substrate on reduction 
(Reaction condition: $0.8 \mathrm{ml} / \mathrm{ml} \mathrm{CBR,} \mathrm{V}_{\mathrm{o}} / \mathrm{V}_{\mathrm{T}}$ 12.5:10, $2.38 \mathrm{mmol} / \mathrm{L}$ oxcarbazepine, $0.08 \mathrm{~mol} / \mathrm{L}$ NADH, 180 $\mathrm{rpm}, 30^{\circ} \mathrm{C}$ )

\subsection{Effect of substrate concentration and reaction time on reduction}

Substrate concentration has a great effect on reduction. High concentration substrate is toxic to interface-assembled enzymes while low concentration substrate leads to the low productive efficiency [19]. The effect of different substrate concentration on reduction was investigated in the toluene /Tris-HCl biphasic system. Figure 7(a) showed that the conversion reached above $90 \%$ after 6 hours when the oxcarbazepine concentration was from 1.98 to $3.97 \mathrm{mmol} / \mathrm{L}$. The conversion decreased significantly when the oxcarbazepine was above $3.97 \mathrm{mmol} / \mathrm{L}$. Figure 7(b) showed that the enantiometric excess of S-licarbazepine was in the range of $95.6 \% \sim 98.2 \%$ when substrate concentration was $1.98 \sim 3.97 \mathrm{mmol} / \mathrm{L}$. Therefore, the optimum substrate concentration was $3.97 \mathrm{mmol} / \mathrm{L}$. The optimal reaction time is $6 \mathrm{~h}$.

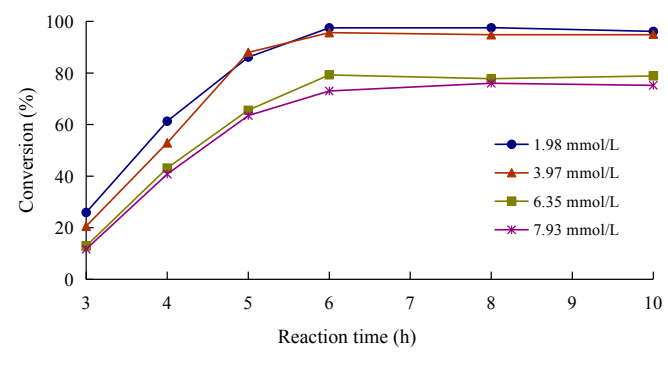

(a)

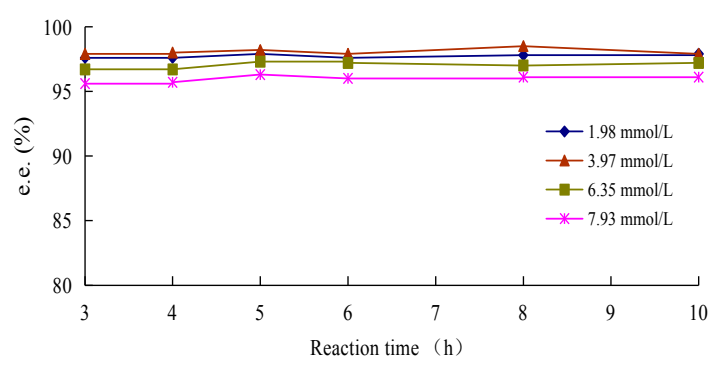

(b)

Figure 7. Effect of substrate concentration on reduction

(Reaction condition: $0.8 \mathrm{ml} / \mathrm{ml} \mathrm{CBR}, \mathrm{V}_{\mathrm{o}} / \mathrm{V}_{\mathrm{T}}$ 12.5:10, $0.08 \mathrm{~mol} / \mathrm{LNADH}, 60 \mathrm{~g} / \mathrm{L}$ ethanol, $180 \mathrm{rpm}, 30{ }^{0} \mathrm{C}$ )

\subsection{Effect of temperature on reduction}

Reaction temperature plays a key role in catalytic efficiency of interface-assembled carbonyl reductase. It can influence the activity and stability of the enzymes as well as the reaction equilibrium [20-21]. Figure 8 showed that the conversion and enantiometric excess of S-licarbazepine decreased when the temperature was over 30 ${ }^{0} \mathrm{C}$. Probably, the structure of interface-assembled enzymes was destroyed at high temperature. The optimal temperature was $30{ }^{\circ} \mathrm{C}$ for reduction of oxcarbazepine. 


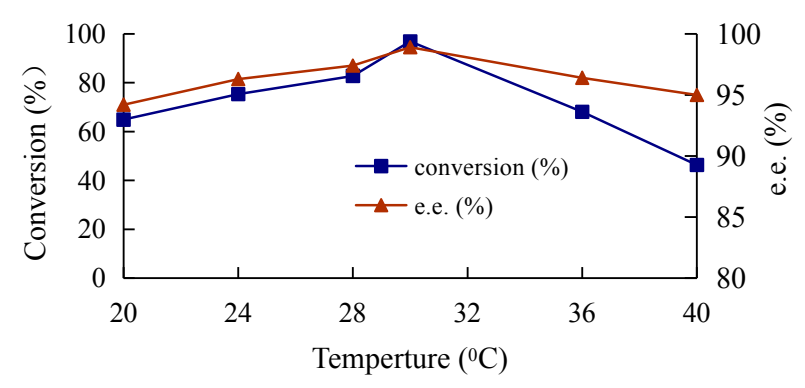

Figure 8. Effect of temperature on reduction

(Reaction condition: $0.8 \mathrm{ml} / \mathrm{ml} \mathrm{CBR}, \mathrm{V}_{\mathrm{o}} / \mathrm{V}_{\mathrm{T}}$ 12.5:10, $3.97 \mathrm{mmol} / \mathrm{L}$ oxcarbazepine, $0.08 \mathrm{~mol} / \mathrm{L} \mathrm{NADH}, 60 \mathrm{~g} / \mathrm{L}$ ethanol, $180 \mathrm{rpm}$ )

\subsection{Effect of shaker speed on reduction}

The optimal shaker speed was benefit for the mass transfer. The effect of shaker speed on the conversion and enantiometric excess of S-licarbazepine were investigated from 100 to $200 \mathrm{rpm}$. Figure 9 showed that the conversion increased with increase of the shaker speed. The change of shaker speed almost had no influence on the enantiometric excess of S-licarbazepine. The optimal shaker speed was $180 \mathrm{rpm}$.

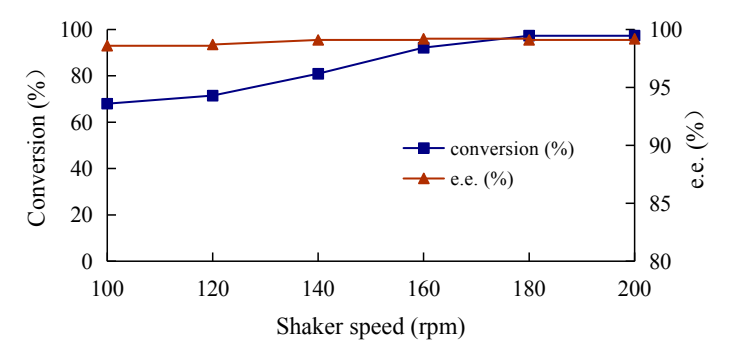

Figure 9. Effect of shaker speed on reduction

(Reaction condition: $0.8 \mathrm{ml} / \mathrm{ml} \mathrm{CBR,} \mathrm{V}_{\mathrm{o}} / \mathrm{V}_{\mathrm{T}}$ 12.5:10, $3.97 \mathrm{mmol} / \mathrm{L}$ oxcarbazepine, $0.08 \mathrm{~mol} / \mathrm{L}$ NADH , $60 \mathrm{~g} / \mathrm{L}$ ethanol, $30^{\circ} \mathrm{C}$ )

2.10 Comparison of biotransformation process in aqueous and in toluene/Tris- $\mathrm{HCl}$ biphasic system with free CBR and CBR-PS as catalyst

Biotransformation of oxcarbazepine was studied in detail by free carbonyl reductase and interface-assembled carbonyl reductase in aqueous and toluene /Tris-HCl biphasic system in order to learn the catalytical efficiency of interface-assembled carbonyl reductase in toluene/Tris-HCl biphasic system. Figure 10(a) showed that the highest conversion was obtained with interface-assembled carbonyl reductase as catalyst in toluene/Tris-HCl biphasic system. Conversion decreased rapidly after 6 hours with free carbonyl reductase as catalyst in toluene/Tris-HCl biphasic system. Probably, free 
enzyme lost the activity in the presence of toluene. Figure 10(b) showed that the enantiometric excess of S-licarbazepine was above $95 \%$ with free or interface-assembled carbonyl reductase in aqueous or toluene/Tris- $\mathrm{HCl}$ biphasic system. It indicated that the interface-assembled carbonyl reductase was benefit for the synthesis of S-licarbazepine.

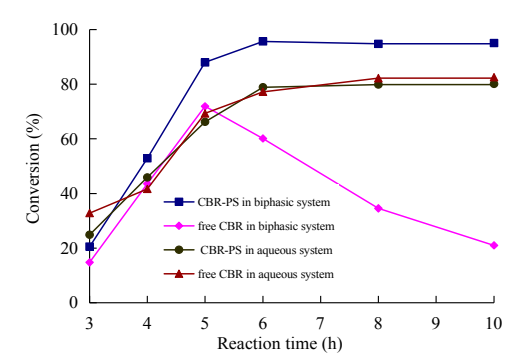

(a)

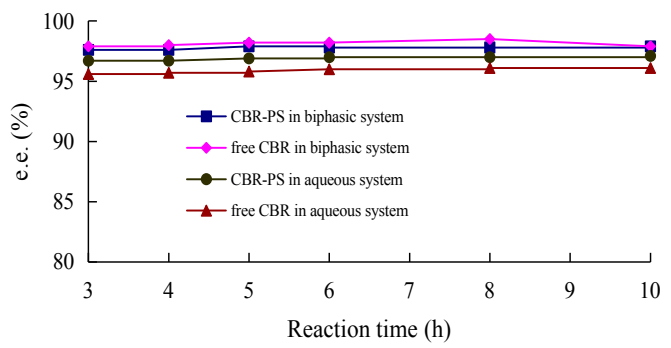

(b)

Figure 10. Effect of interface-assembled carbonyl reductase and free carbonyl reductase on reduction

(Biphasic system reaction condition: $\mathrm{V}_{\mathrm{o}} / \mathrm{V}_{\mathrm{T}}$ 12.5:10, $3.97 \mathrm{mmol} / \mathrm{L}$ oxcarbazepine, $0.08 \mathrm{~mol} / \mathrm{L} \mathrm{NADH}, 60 \mathrm{~g} / \mathrm{L}$ ethanol, $30{ }^{\circ} \mathrm{C}, 180 \mathrm{rpm}$; aqueous system reaction: $3.97 \mathrm{mmol} / \mathrm{L}$ oxcarbazepine, $0.08 \mathrm{~mol} / \mathrm{L} \mathrm{NADH}, 60 \mathrm{~g} / \mathrm{L}$ ethanol, $30^{\circ} \mathrm{C}, 180 \mathrm{rpm}$ )

\section{Materials and Methods}

\subsection{Materials}

Oxcarbazepine and S-licaebazepine were purchased from shanghai ZiQi biological technology Co. Polystyrene was purchased from Aladdin Industrial Corporation. Bacillus anthracis CGMCC NO.12337 was screened from the soil in the Zhejiang University of Technology and preserved in China General Microbiological Culture Collection Center.

\subsection{Preparation of carbonyl reductase $(C B R)$}

Slant medium for strain storage was composed of $3 \mathrm{~g} / \mathrm{L}$ yeast extract, $5 \mathrm{~g} / \mathrm{L}$ $\left(\mathrm{NH}_{4}\right)_{2} \mathrm{SO}_{4}, 0.25 \mathrm{~g} / \mathrm{L} \mathrm{MgSO}_{4}, 1 \mathrm{~g} / \mathrm{L} \mathrm{K}_{2} \mathrm{HPO}_{4} \cdot 3 \mathrm{H}_{2} \mathrm{O}, 1 \mathrm{~g} / \mathrm{L} \mathrm{KH}_{2} \mathrm{PO}_{4}$ and $20 \mathrm{~g} / \mathrm{L}$ agar. The liquid medium was composed of $12 \mathrm{~g} / \mathrm{L}$ glucose, $3 \mathrm{~g} / \mathrm{L}$ yeast extract, $5 \mathrm{~g} / \mathrm{L}$ $\left(\mathrm{NH}_{4}\right)_{2} \mathrm{SO}_{4}, 0.25 \mathrm{~g} / \mathrm{L} \quad \mathrm{MgSO}_{4}, 1 \mathrm{~g} / \mathrm{L} \mathrm{K}_{2} \mathrm{HPO}_{4} \cdot 3 \mathrm{H}_{2} \mathrm{O}$ and $1 \mathrm{~g} / \mathrm{L} \mathrm{KH}_{2} \mathrm{PO}_{4}$. The fermentation medium was composed of $40 \mathrm{~g} / \mathrm{L}$ glucose, $15 \mathrm{~g} / \mathrm{L}$ peptone, $0.25 \mathrm{~g} / \mathrm{L}$ $\mathrm{MgSO}_{4}, 1 \mathrm{~g} / \mathrm{L} \mathrm{K}_{2} \mathrm{HPO}_{4} \cdot 3 \mathrm{H}_{2} \mathrm{O}$ and $1 \mathrm{~g} / \mathrm{L} \mathrm{KH}_{2} \mathrm{PO}_{4}$. The strain picked from the slant 
medium was inoculated into $100 \mathrm{ml}$ liquid medium and cultivated in $30{ }^{\circ} \mathrm{C} 120 \mathrm{rpm}$ shaker for $24 \mathrm{~h}$. The seed culture was transferred into $500 \mathrm{ml}$ fermentation medium by $10 \%$ inoculum concentration. After cultivated for $36 \mathrm{~h}$, the cells were harvested by centrifugation (8000 rpm $10 \mathrm{~min})$.

Cell sediment (dry weight is $5 \mathrm{~g}$ ) gained above was dispersed in the $100 \mathrm{ml}$ Tris- $\mathrm{HCl}$ buffer (0.02 M, pH 7.0). Crude carbonyl reductase was obtained after cells were broken by ultrasonic processor. The mixed solution was centrifuged $(8000 \mathrm{rpm}, 10$ min). The sediment was discarded. Ammonium sulfate was added into the supernatant containing crude enzyme. The saturability of ammonium sulfate was adjusted to $60 \%$. The sample was processed by slow stirring in the ice-water bath for 2 hours. The sediment was gained by centrifugation (8000 rpm $10 \mathrm{~min})$. The sediment was dissolved in $2 \mathrm{ml}$ Tris- $\mathrm{HCl}$ buffer $(0.02 \mathrm{M}, \mathrm{pH} 7.0)$ to form the carbonyl reductase sample.

\subsection{Preparation of interface-assembled carbonyl reductase}

$1.5 \mathrm{ml}$ Tris- $\mathrm{HCl}$ buffer $(0.02 \mathrm{M}, \mathrm{pH} 7.0)$ containing $0.5 \mathrm{ml}$ carbonyl reductase (CBR) was added into $10 \mathrm{ml}$ organic solvent containing $10 \mathrm{mg}$ polystyrene (PS). The reaction was carried out at $180 \mathrm{rpm}, 30^{\circ} \mathrm{C}$ for 1 hour in the darkness. The CBR-PS assembled at the interfacial region after centrifugation (10000 rpm, $10 \mathrm{~min})$. The interfacial region was further purified by washing with Tris- $\mathrm{HCl}$ buffer and organic solvent alternatively for 3 times. This process can remove residual free CBR and PS.

\subsection{Asymmetric reduction of oxcarbazepine to prepare S-licarbazepine}

Interface-assembled carbonyl reductase was used as catalyst to synthesize S-licarbazepine in organic solvent/Tris-HCl buffer biphasic system. 1.98-9.52 mmol/L oxcarbazepine was added into a $100 \mathrm{ml}$ shaking flask containing $10 \mathrm{ml}$ Tris-HCl buffer (0.02 M, pH 3.0-8.0), 3-20 ml organic solvent, $1 \mathrm{ml}$ NADH (0.02-0.09 M) and 0-70 g/L co-substrates. The reaction was carried out at $30{ }^{\circ} \mathrm{C}$, 100-200 rpm for 3-10 h.

Tris-HCl buffer phase and organic phase were layered obviously after centrifugation (10000 rpm, $10 \mathrm{~min}$ ). After filtrated, the organic phase containing S-licarbazepine can 
be analyzed by HPLC. Ethyl acetate was used to extract S-licarbazepine from the Tris-HCl buffer phase for three times. Ethyl acetate containning S-licarbazepine was used for futher analysis. Self-assembled carbonyl reductase formed in the interface of organic/Tris-HCl biphasic system was showed in Figure 11.

\subsection{Analysis methods}

The conversion of oxcarbazepone was analyzed by HPLC equipped with a reverse-phase C18 HPLC column (4 $\mathrm{mm} \times 25 \mathrm{~cm} \times 5 \mu \mathrm{m}$; Merck, Germany). The mobile phase was acetonitrile/0.1\% ethanol solution (40:60). Detection wavelength was $210 \mathrm{~nm}$. Flow rate of mobile phase was $1.0 \mathrm{ml} / \mathrm{min}$. Column temperature was 25 ${ }^{0} \mathrm{C}$. The injection volume of sample was $10 \mu \mathrm{l}$.

The enantiometric excess of S-licarbazepine was analyzed with HPLC equipped with chiral column OD-H $(4.6 \mathrm{~mm} \times 25 \mathrm{~cm} \times 5 \mu \mathrm{m}$; Daicel, Japan). The mobile phase was hexane containning $0.05 \% \mathrm{THF} /$ isopropanol (98:2). Detection wavelength was 210 $\mathrm{nm}$. Flow rate of mobile phase was $0.8 \mathrm{ml} / \mathrm{min}$. Column temperature was $24.8{ }^{0} \mathrm{C}$. The injection volume of sample was $10 \mu \mathrm{l}$.

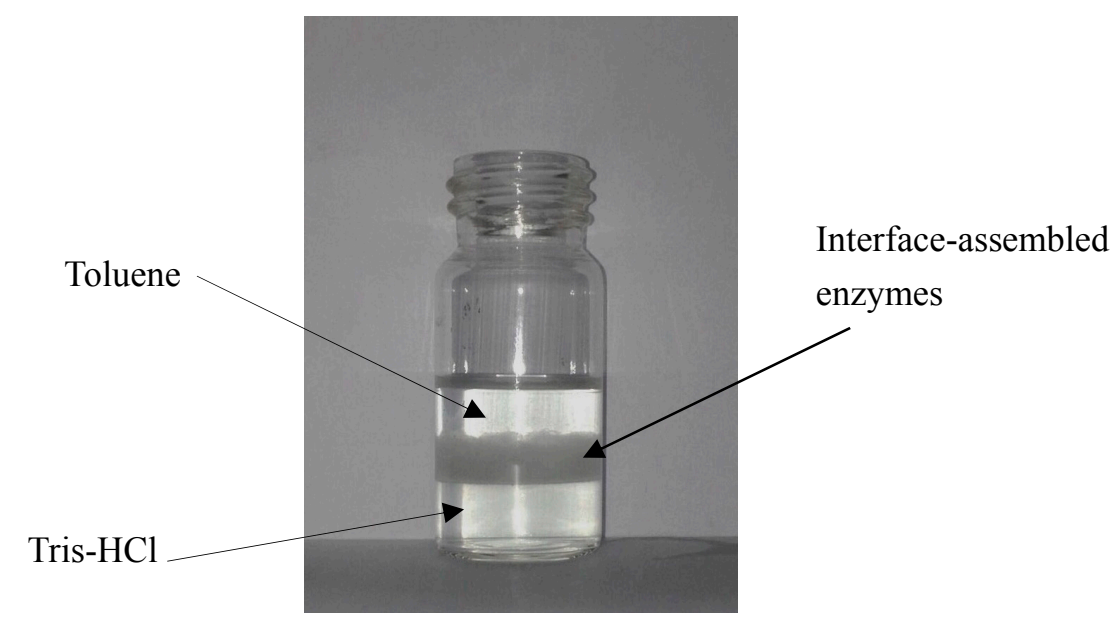

Figure 11. Self-assembled carbonyl reductase formed in the interface of organic/ Tris-HCl biphasic system (cross-sectional area is $16.6 \mathrm{~cm}^{2}$ )

3.6 Comparison experiment with free or interface-assembled carbonyl reductase in aqueous or toluene/Tris-HCl biphasic system

In order to learn the catalytic efficiency of interface-assembled carbonyl reductase, comparison experiments were carried out with free or interface-assembled carbonyl 
reductase in aqueous or toluene/Tris- $\mathrm{HCl}$ biphasic system. $0.8 \mathrm{ml} / \mathrm{ml}$ free or interface-assembled carbonyl reductase were added into $100 \mathrm{ml}$ shaking flask which contains $10 \mathrm{ml}$ Tris- $\mathrm{HCl}$ buffer $(0.02 \mathrm{M}, \mathrm{pH} 3.0-8.0), 12.5 \mathrm{ml}$ toluene, $1 \mathrm{ml} \mathrm{NADH}$, $60 \mathrm{~g} / \mathrm{L}$ ethanol and $3.97 \mathrm{mmol} / \mathrm{L}$ oxcarbazepine respectively. The reaction was carried out at $30{ }^{\circ} \mathrm{C}, 180 \mathrm{rpm}$ for 3-10 h. In addition, reaction conditions in single aqueous system were as follows: $22.5 \mathrm{ml}$ Tris- $\mathrm{HCl}$ buffer (0.02 M, pH 3.0-8.0), $1 \mathrm{ml} \mathrm{NADH,}$ $60 \mathrm{~g} / \mathrm{L}$ ethanol and $3.97 \mathrm{mmol} / \mathrm{L}$ oxcarbazepine, $0.8 \mathrm{ml} / \mathrm{ml}$ free or interface-assembled carbonyl reductase, $30{ }^{\circ} \mathrm{C}, 180 \mathrm{rpm}$ for $3-10 \mathrm{~h}$.

\section{Conclusion}

Interface-assembled carbonyl reductase was prepared at the surface of oil and water phase. S-licarbazepine was synthesized by asymmetric reduction of oxcarbazepine with interface-assembled carbonyl reductase as catalyst in toluene/Tris-HCl biphasic system. Carbonyl reductase was connected with polystyrene at the surface of organic solvent and tris-HCl. Toluene/Tris-HCl was selected as optimal biphasic system for preparation of interface-assembled carbonyl reductase. Influence of reaction conditions on reduction of oxcarbazepine was investigated. Reaction conditions for synthesis of S-licarbazepine were optimized. The optimal condition were as follows: $3.75 \mathrm{mg} / \mathrm{ml}$ polystyrene, $0.8 \mathrm{ml} / \mathrm{ml}$ carbonyl reductase, volume ratio of toluene and Tris-HCl buffer 12.5:10, $0.08 \mathrm{~mol} / \mathrm{L} \mathrm{NADH,} 60 \mathrm{~g} / \mathrm{L}$ ethanol as co-substrate, 3.97 mmol/L oxcarbazepine, $30{ }^{\circ} \mathrm{C}, 180 \mathrm{rpm} 6 \mathrm{~h}$. The conversion and enantiometric excess of S-licarbazepine got to $97.39 \%$ and $99.6 \%$.

Acknowledgment: We thank the Zhejiang Provincial Natural Science Foundation of China (LY15B060005) for the financial support. 


\section{References:}

1. Falcão, A.; Maia, J.; Almeida, L.; Mazur, D.; Gellert, M.; Soares-da-Silva, P. Effect of gender on the pharmacokinetics of eslicarbazepine acetate (BIA 2-093), a new voltage-gated sodium channel blocker. Biopharm. Drug. Dispos. 2007, 28, 249-256.

2. Alves, G.; Figueiredo, I.; Castel-Branco, M.; Loureiro, A.; Falcão, A.; Caramona, M. Simultaneous and enantioselective liquid chromatographic determination of eslicarbazepine acetate, s-licarbazepine, r-licarbazepine and oxcarbazepine in mouse tissue samples using ultraviolet detection. Anal. Chim. Acta. 2007, 596, 132-140.

3. Modukuru, N.K.; Sukumaran, J.; Collier, S.J.; Chan, A.S.; Gohel, A.; Huisman, G.W. Development of a practical, biocatalytic reduction for the manufacture of S-licarbazepine using an evolved ketoreductase. Org. Process. Res. Dev. 2014, $18,810-815$.

4. Ou, Z.M.; Shi, H.B.; Sun, X.Y.; Shen, W.H. Synthesis of S-licarbazepine by asymmetric reduction of oxcarbazepine with Saccharomyces cerevisiae CGMCC No. 2266. J. Mol. Catal B: Enzyme. 2011, 72, 294-297.

5. Ravinder, B.; Reddy, S.R.; Sridhar, M.; Mohan, M.M.; Srinivas, K.; Reddy, A.P. An efficient synthesis for eslicarbazepine acetate, oxcarbazepine, and carbazepine. Tetrahedron Lett. 2013, 54, 2841-2844.

6. Ishida, N.; Suzuki, T.;1 Tokuhiro, K.; Nagamori, E.; Onishi, T.; Saitoh, S. D-lactic acid production by metabolically engineered Sacchromyces cerevisiae. J. Biosci. Bioeng. 2006, 101, 172-177.

7. Singh, M.; Singh, S.; Deshaboina, S.; Krishnen, H.; Lloyd, R.; Holt-Tiffin, K.; Bhattacharya, A.; Bandichhor, R. Asymmetric reduction of a key intermiediate of eslicarbazepine acetate using whole cell biotransformation in a biphasic medium. Catal. Sci. Tech. 2012, 2, 1602-1605.

8. Colonna, S.; Gaggero, N.; Richelmi, C.; Pasta, P. Recent biotechnological developments in the use of peroxidases. Trends in Biotechnol. 1999, 17, $163-168$. 
9. Zou, S.P.; Yan, H.W.; Hu, Z.C.; Zheng, Y.G. Enzymatic resolution of epichlorohydrin catalyzed by whole cells in an organic solvent/ buffer biphasic system. Chin. J. Catal. 2013, 34, 1339-1347.

10. D'Souzaschorey, C.; Chavrier, P. ARF proteins: roles in membrane traffic and beyond. Natu. Rev. Mol. Cell. Biolo. 2006, 7, 347-358.

11. Wang, L.F.; Zhu, G.Y.; Wang, P.; Newby, B.Z. Self-Assembling of polymer-enzyme conjugates at oil/water interfaces. Biotechnol. Prog. 2005, 21, 1321-1328.

12. Zhu, G.Y.; Wang, P. Polymer-enzyme conjugates can self-assemble at oil/water interfaces and effect interfacial biotransformations. J. Am. Chem. Soc. 2004, 126, 1132- 1133.

13. Hickel, A.; Radke, C.J.; Blanch, H.W.; Hydroxynitrile lyase at the diisopropyl ether/water interface: evidence for interfacial enzyme activity. Biotechnol. Bioeng. 1999, 65, 425-436.

14. Jia, H.; Zhu, G.; Vugrinovich, B.; Kataphinan, W.; Reneker, D.H.; Wang, P. Enzyme-carrying polymeric nanofibers prepared via electrospinning for use unique biocatalysts. Biotechnol. Prog. 2002, 18, 1027-1032.

15. Fainerman, V.B.; Miller, R. Equilibrium and dynamic characteristics of protein adsorption layers at gas-liquid interfaces: theoretical and experimental data. Colloid. J. 2005, 67, 393-404.

16. León, R.; Fernandes, P.; Pinheiro, H.M.; Cabral, J.M.S. Whole-cell biocatalysis in organic media. Enzyme Microb. Technol. 1998, 23, 483-500.

17. Rodriguez, C.; Lavandera, I.; Gotor, V. Recent advances in cofactor regeneration systems applied to biocatalyzed oxidative processes. Current Org. Chem. 2012, $16,2525-2541$.

18. Kometain, T.; Yoshii, H.; Matsuno, R. Large-scale production of chiral alcohol with baker's yeast. J. Mol. Catals B: Enzymatic. 1996, 1, 45-52.

19. He, J.Y.; Sun, Z.H.; Zheng, P.; Han, L. Asymmetric reduction of ethyl 4-chloro-3-oxobutanoate in an aqueous/organic solvent biphasic system with microorganism. J. Chem. Eng. Chin. Univ. 2007, 21, 310-315. 
20. Philips, R.S. Temperature modulation of the stereochemistry of enzymatic catalysis: prospects for exploitation. Trends Biotechnol. 1996, 14, 13-16.

21. Xie, Q.; Wu, J.P.; Lin, L.; Xu, G.; Yang, L.R. Purification and characterization of a carbonyl reductase form Candida pseudotropicalis. J. Chem. Eng. Chin. Univ. 2009, 23, 92-98.

(C) 2017 by the authors. Licensee Preprints, Basel, Switzerland. This article is an open access article distributed under the terms and conditions of the Creative Commons by Attribution (CC-BY) license (http://creativecommons.org/licenses/by/4.0/). 